\title{
PATHOGENETIC ROLE OF THROMBOCYTES IN THE DEVELOPMENT OF AUTOIMMUNE PATHOLOGY OF THE THYROID GLAND
}

\author{
I.Yu. Bahmut, O.O. Halmyz, S.M. Hramatiuk, A.V. Titkova
}

Kharkiv Medical Academy of Postgraduate Education, Kharkiv

This work is a fragment of KhMAPO "Cellular-molecular mechanisms of inflammation associated with chronic diseases», the state registration number 015 U001186 "Pathochemical mechanisms of action of radioiodine on the organism and principles of their early diagnosis and correction", state registration number 0117 U000589.

Враховуючи значення тромбоцитів у механізми запалення та аутоімунному процесі, метою даного дослідження було експериментально відповісти на просте питання, тромбоцити людей з аутоімунним єу-, гіпер- та гіпотиреозом виявляють характеристики підвищеної активності. В дослідженні приймали участь 35 пацієнтів з аутоімунним захворюванням щитоподібної залози, позитивних як до TPO-Ab, так і до Tg - Ab i з підвищеним рівнем TTГ 50 пацієнтів з підвищеною концентрацією T4 та / або T3, і пригніченим рівнем TTГ, наявністю антитіл TSHR та / aбо антимікросомальних антитіл. У результаті проведенного дослідження встановлено, що АДФ-індукована агрегація, тобто ії показники залежать від концентрації індуктора агрегації. За результатами проведенного дослідження нами було висунуто гіпотезу, що PMPS можуть взаємодіяти з циркулюючими аутоантитілами і С1q, що беруть участь у формуванні імунних комплексів, які можуть бути патофізіологічною причиною імунної відповіді.

Ключові слова: агрегація тромбоцитів, антимікросомальні антитіла, щитоподібна залоза

Taking into account the importance of platelets in the mechanisms of inflammation and the autoimmune process, the aim of this study was to experimentally answer a simple question: whether platelets in people with autoimmune euthyroidism, hyperthyroidism and hypothyroidism exhibit the characteristics of high activity. The study included 35 patients with autoimmune thyroid gland disease, positive for both TRO-Ab and Tg-Ab, and with elevated TTH, and 50 patients with elevated T4 and / or T3 concentrations and depressed levels of TTH, presence of TSHR antibodies, and / or antimicrosomal antibodies. As a result of this study, it was found that ADP-induced aggregation, that is, its parameters depend on the concentration of the aggregation inductor. According to the results of our study, we hypothesized that PMPs can interact with circulating autoantibodies and $\mathrm{C1q}$ involved in the formation of immune complexes, which can be a pathophysiological cause of the immune response.

Key words: platelet aggregation, antimicrosomal antibodies, thyroid gland

Participation of platelets in autoimmune diseases has been extensively disclosed in the scientific literature, and their disrupted functioning is a sign of idiopathic thrombocytopenic purpura (ITP), rheumatoid arthritis, systemic lupus erythematosus, antiphospholipid syndrome and multiple sclerosis and many other diseases $[1,2]$.

The pro-inflammatory activity of the platelets leads to disrupted hemostatic balance and increases the risk of cardiovascular disease. Studies show that people with autoimmune thyroid disease (AIT) are prone to developing other autoimmune diseases and cardiovascular diseases. These include ITP and thrombocytopenia, associated with disorders in the structure and function of platelets [3]. A potential mechanism that may be associated with AIT is the immunogenic destruction of platelets by circulating autoantibodies that respond to both target antigens and epitopes located on the surface of the platelets, typically typical glycoprotein receptors. Blood platelets are multifunctional blood cells that are involved in the initiation of atheroma, endothelial dysfunction, and modulation of inflammatory and immune responses [4]. Due to their multifaceted proinflammatory activity, platelets can be involved in the pathogenesis of autoimmune diseases of the thyroid gland. However, there is no data on the activity of platelets and their pathophysiological significance in autoimmune diseases of the thyroid gland [5-8].

Taking into account the importance of platelets in the mechanisms of inflammation and the autoimmune process, the aim of this study was to experimentally answer the simple question, platelets of people with autoimmune euthyroidism, hyperthyroidism and hypothyroidism whether exhibit characteristics of high activity or not.

\section{Materials and methods}

The study included 94 patients who were diagnosed with autoimmune thyroiditis.

We examined 35 patients with autoimmune thyroid gland disease, positive for both TRO-Ab and Tg-Ab, and with elevated TTH and 50 patients with elevated T4 and / or T3 concentrations, and depressed levels of TTH, presence of TSHR antibodies, and / or anti-microsomal antibodies. All patients did not have other autoimmune acute or chronic inflammatory diseases. The group of apparently healthy people comprised 30 donors without any autoimmune or chronic inflammatory disease.

All patients and donors who participated in the study were characterized by the correct number of platelets and did not use antiplatelet or immunomodulatory drugs for at least 14 days before the study.

All procedures were conducted in accordance with the Helsinki Declaration and were approved by the Bioethics Committee of the Kharkiv Medical Academy of Postgraduate Education, Ukraine.

Platelet aggregation was investigated using physio-

\footnotetext{
* To cite this English version: I.Yu. Bahmut, O.O. Halmyz, S.M. Hramatiuk, A.V. Titkova. Pathogenetic role of thrombocytes in the development of autoimmune pathology of the thyroid gland. // Problemy ekologii ta medytsyny. - 2018. - Vol 22, № 5-6. - P. 10-13.
} 
logical agonists: adenosine diphosphate (ADP) (10 $\mu \mathrm{mol} / \mathrm{L})$, collagen $(2 \mu \mathrm{g} / \mathrm{ml})$, or arachidonic acid $(0.5$ $\mathrm{mmol} / \mathrm{L}$ ), measured in plasma with platelets using turbidimetric method on the optical Chrono-Log Agrometers

Aggregation of platelets with ADP is a diagnostic test that evaluates the activated platelet aggregation reaction using a special aggregation inducer - ADP. The analysis was carried out with the aid of an aggregometer, which registered the figures in a continuous mode and reflected them in the form of the curve of the line. Interpretation of research results is based on aggregation (one-way or two-way, complete or not, inverse or irreversible).

We studied antiplatelet autoantibodies and their titres in patient, using the immunological method; the titration of antiplatelet autoantibodies not lower than 1:20 was considered diagnostically significant.

The analysis of platelet cytometry as a result of an agonist-stimulated experiment (ADP $2.5 \mu \mathrm{g} / \mathrm{ml}$, collagen $20 \mu \mathrm{g} / \mathrm{ml}$ ) was conducted using AutoMAX Flow Cytometer (San Diego, CA, USA). After fixation ( $1 \%$ Cellfix solution), blood samples were stained with saturated concentrations of IgG1 monoclonal antibodies: PeridinChlorophyll Protein Complex (PerCp) is a conjugated anti-CD61 antibody (platelet constitutive surface receptor that distinguishes platelets from other cells) and fluorescein isothiocyanate (FITC) ) - conjugated antibody PAC-1. Each fluorescence measurement of 10,000 platelets (CD61/PerCP-positive objects) was measured.

FITC fluorescence was detected in each sample and the percentage of PAC-1-positive platelets determined relative to the total platelet count (10,000 CD61 / PerCPpositive cells). Based on the size and grain size, we determined the direct light scattering (DSC) against the side scattering sites (SSC) in CD61 / PerCP-positive objects, the formation of platelet subpopulations, depending on the degree of activation of cells: aggregates (PA) and platelet derivatives of microparticles (PMP) Using the reference balls, we evaluated the DSC.

Statistical analysis of the results was carried out using the computer software package for statistical information processing Statistica 6.1 (StatSoft, Inc., USA).

\section{Results and discussion}

The systemic nature of disruptions in both cellular and humoral immunity with AIT can cause the emergence of autoantibodies not only in the follicular cells of the thyroid gland, but also in other tissues and organs.

As one can observe at the diagram (Figure 1), the diagnostically significant antibody titer was detected in $16 \%$ of subjects. The majority of patients with AIT (79\%) had a low titration of antiplatelet antibodies 1:10. And only 5\% of antibodies to platelets were not detected at all. It allows considering antiplatelet autoantibodies as a possible pathogenic factor and a direct factor of disrupted function of platelets in AIT.

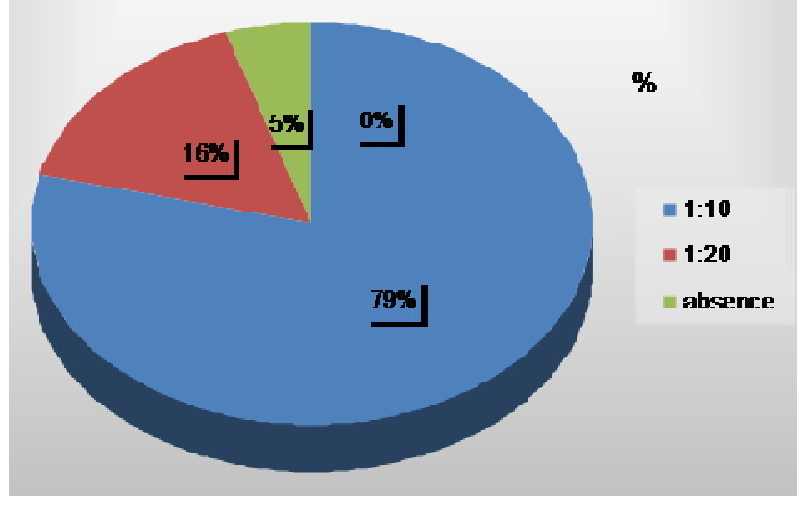

Figure 1. Titration of antitrombocyte autoantibodies in patients with AIT

The results of an experimental study on the use of inducers of platelet aggregation in patients with autoimmune thyroid disease are presented in Table 1. According to the results of the research, it was found that the maximum aggregation of platelets, as well as the rate of achieving the maximum platelet count, is observed in the collagen of induced aggregation. It is known that the genetic types of collagen are different by the composition of chains and localization, which can become the next stage of our research [9].

Table 1

Results of experimental research on the use of inducers of platelet aggregation

\begin{tabular}{|l|c|c|c|c|c|c|}
\hline \multirow{2}{*}{ Indexes } & \multicolumn{3}{|c|}{ Hyperthyroidism } & \multicolumn{3}{c|}{ Hypothyroidism } \\
\cline { 2 - 7 } & $\begin{array}{c}\text { Collagen } \\
20 \mu \mathrm{g} / \mathrm{ml}\end{array}$ & $\begin{array}{c}\mathrm{ADP} \\
2.5 \mu \mathrm{g} / \mathrm{ml}\end{array}$ & $\begin{array}{c}\mathrm{SA} \\
\mathrm{c.u}\end{array}$ & $\begin{array}{c}\text { Collagen } \\
20 \mu \mathrm{m} / \mathrm{ml}\end{array}$ & $\begin{array}{c}\text { ADP } \\
2.5 \mu \mathrm{g} / \mathrm{ml}\end{array}$ & $\begin{array}{c}\text { SA } \\
\mathrm{c} . \mathrm{u}\end{array}$ \\
\hline $\begin{array}{l}\text { Aggregation activity of } \\
\text { platelets, \% }\end{array}$ & $33.35 \pm 10.57^{*}$ & $19.15 \pm 8.04$ & $11.50 \pm 2.86$ & $39.25 \pm 8.32^{*}$ & $23.34 \pm 7.88$ & $12.61 \pm 3.03$ \\
\hline $\begin{array}{l}\text { The platelets rate of } \\
\text { reaching the maximum } \\
\text { value tga, with MASi }\end{array}$ & $1.08 \pm 0.22^{*}$ & $1.87 \pm 0.34^{*}$ & $1.38 \pm 0.36$ & $1.45 \pm 0.36^{*}$ & $2.25 \pm 0.25^{*}$ & $1.96 \pm 0.41$ \\
\hline $\begin{array}{l}\text { Maximum aggregate size } \\
\text { MASi }\end{array}$ & $1.27 \pm 0.11^{*}$ & $1.92 \pm 0.19^{*}$ & $1.36 \pm 0.15$ & $1.66 \pm 0.15^{*}$ & $2.27 \pm 0.17^{*}$ & $1.85 \pm 0.14$ \\
\hline $\begin{array}{l}\text { Time to achieve maximum } \\
\text { aggregation }\end{array}$ & $181.75 \pm 69.03$ & $250.14 \pm 22.40$ & $218.94 \pm 22.74$ & $189.53 \pm 61.12$ & $253.29 \pm 19.09$ & $232.67 \pm 24.15$ \\
\hline
\end{tabular}

Note: SA - spontaneous aggregation, ADP-induced aggregation, tga - aggregation rate, MASi - maximum aggregate size, tga, MASi the rate of reaching the maximum value of aggregates, * - a reliable difference $p \leq 0,05$

As a result of this study, it was found that ADPinduced aggregation, that is, its parameters, depend on the concentration of the aggregation inductor. At concentration of ADP $2,5 \mu \mathrm{g} / \mathrm{ml}$ the maximum size of aggregates is observed, the rate of achievement of the maximum size of aggregates increases, and time of achievement of maximum aggregation does not depend on concentration of ADP in all groups of patients. The highest rates of hypotensive and induced aggregation were observed in pa-

tients with autoimmune thyroid disturbances with hyperfunction. According to the results obtained in the course of experimental study, it can be assumed that ADP - the most important physiological $\mathrm{Ca} 2+$ - is a dependent aggregation inducer, which implements the pathophysiological effect of fibrinogen, albumin and aggregons [10]. In the course of experiment, it was established that aggregation is reversible at low concentrations of ADP and irreversible - at high, releasing ADP from cells. The kinet- 
ics of the transformation of discoid platelets into spherical ones does not depend on the concentration of ADP and does not correlate with the restoration of their shape. Aggregation initiates the binding of ADP to platelets, causing a depolarization of the plasma membrane, which provokes loss of discoid form and the appearance of pseudopodia.

Two components of the primary ADP aggregation curve are established: slow - at minimum concentrations of ADP, fast - at a concentration of 0.4-0.8 $\mu \mathrm{M}$. The effect of ADP on platelet aggregation depends on the $\mathrm{pH}, \mathrm{t}^{\circ}$, the concentration of glycosaminoglycans, divalent ions, especially $\mathrm{Ca} 2+$ and $\mathrm{Mn}$, from the hormonal background, physical activity.

The first reaction of platelet aggregation is a change in their shape, the discoid form becomes spherical, and at the same time there are pseudo-events. After the completion of primary aggregation, the steepness of aggregation curve decreases; during this period, the biologically active compounds that cause a new aggregation wave are released from the platelets. Figure 2 shows examples of aggregation curves of patients with autoimmune thyroid gland pathology using various inducers of aggregation.

Examples of aggregation curves were recorded in the optical unit. Platelet aggregation at stimulation of ADP was $10 \%$ higher for hyperthyroidism $(P<0.005)$ and $8 \%$ for hypothyroidism $(P<0.05)$ when compared with euthyroid condition. Collagen caused $10 \%$ increase in control for hyperthyroidism and $11 \%$ for hypothyroidism ( $P$ $<0.005$ ), whereas spontaneous aggregation was $14.5 \%$ higher for hyperthyroidism $(P<0.05)$ and $18.3 \%$ for hypothyroidism $(P<0.005)$ than in patients with euthyroidism (Fig. 2).
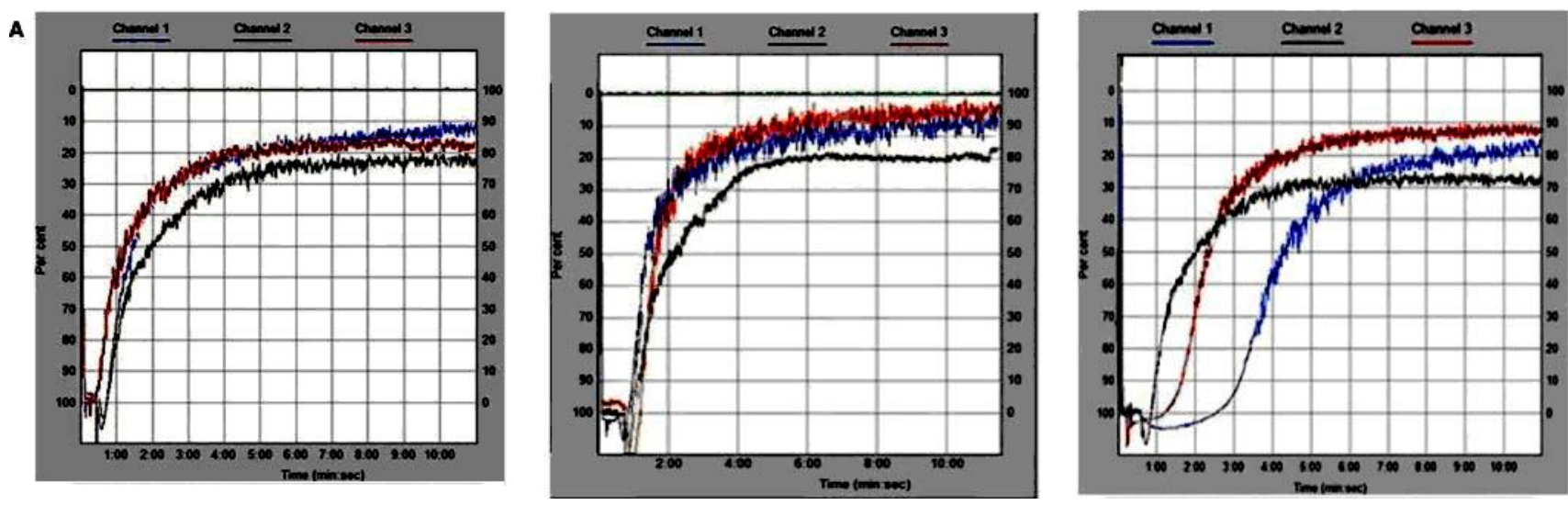

Figure 2. Examples of aggregation curves in patients with autoimmune pathology of the thyroid gland using various inducers of aggregation

Our study is the first to demonstrate the changes of hemostatic thrombocyte function in patients with thyroid gland autoimmune pathology. We have shown that an increased level of platelet aggregation and its generation (vesicular structures formed predominantly during activation and death of cells), as well as greater agonist susceptibility, is crucial for hemostatic platelet function. Excessive production of microparticles induced by constant cell activation may contribute to the development of chronic inflammatory processes and propensity to autoimmune diseases [11-13]. According to the results of our study, we hypothesized that PMPs can interact with circulating autoantibodies and $\mathrm{C} 1 \mathrm{q}$ involved in the formation of immune complexes, which can be a pathophysiological cause of the immune response.

Conclusions. As a result of our study, we found that in samples of whole blood without allocation of platelets significantly reduces the risk of creating artifacts and can illustrate the state of activation of platelets in the blood. Consequently, we can conclude that hyperactivity of platelets is a phenomenon that occurs in the vascular system of patients with AIT. We assume that the pathophysiological cause of anomalies of platelets in patients with autoimmune thyroid disorders is the activation of inflammatory and autoimmune processes, more than hormonal ones. Thus, this is a direction for our further studies.

\section{References}

1. Yegorova E.H. Gemostaticheskaya funktsiya u bol'nykh s zabolevaniyami shchitovidnoy zhelezy / E.H. Yegorova // Translyatsionnaya meditsina. - 2014.- №3 - S. 57-61.
2. Yegorova E.H. Izucheniye pokazateley sistemy gemostaza u bol'nykh s gipotireozom / E.H. Yegorova, T.O. Vavilova, A.M. Ivanov, M.A. Kharitonov, N.L. Kalinina, A.A Tatarkin // Materialy Itog. konf. Voyen.-nauch. o-va slushateley fak. rukovodyashchego med. sostava. Sankt-Peterburg. 5 aprelya 2013g.- SPb.. 2013 - S.57-58.

3. Mel'nichenko G.A., Kakhturiya YU.V., Chazova T.Ye i dr. Osobennosti techeniya klimaktericheskogo perioda $u$ zhenshchin s zabolevaniyami endokrinnoy sistemy // Zhurnal akusherstva i zhenskikh bolezney. — 2009. — № 1. - S. 1-7.

4. Zaydiyeva YA.Z. Gormonoprofilaktika metabolicheskikh narusheniy $u$ zhenshchin $v$ perimenopauze: Avtoref. dis... d-ra med. nauk. - M., 1997. - $36 \mathrm{~s}$.

5. Kalashnikova M.F., Kakhturiya YU.B., Mel'nichenko G.A. Osobennosti peri- i postmenopauzal'nogo perioda $u$ zhenshchin s endokrinnymi zabolevaniyami // Problemy reproduktsii. -2003.

6. Ushkalova S.G. Klimaktericheskiye rasstroystva u zhenshchin $v$ postmenopauze s gipofunktsiyey shchitovidnoy zhelezy i ikh gormonal'naya korrektsiya: Avtoref. dis... kand. med. nauk. - M., 2012. - S. 12-13.

7. Godsland I.F. Effects of postmenopausal hormone replacement therapy on lipid, lipoprotein, an apolipoprotein (a) concentration: analysis of studies published from 1974-2000 // Fertil. Steril. - 2001. - Vol. 75(5). - P. 898-915.

8. Sherman T.S., Chambliss K.L., Gibson L.L. et al. Estrogen acutely activates prostacyclin synthesis in ovine fetal pulmonary artery endothelium // Am. J. Respir. Cell. Mol. Biol. - 2014. - Vol. 26. - P. 610-616.

9. Mori M., Tsukahara F., Yoshioka T., Irie K., Ohta H. Suppression by 17 betaestradiol of monocyte adhesion to vascular endothelial cells is mediated by estrogen receptors // Life Sci. - 2014. - Vol. 75. - P. 599-609.

10. Muhn P., Fuhrmann U., Fritzemeier K. et al. Drospirenone: a novel progestogen with antimineralocorticoid and 
antiandrogenic activity. In Steroid receptors and antihormones // Ann. NY Acad. Sci. - 2015. - 761. - P. 311-331.

11. Araki N. Rapid bioassay for detection of thyroid-stimulating antibodies using cyclic adenosine monophosphate-gated calcium channel and aequorin. / Araki N., lida M., Amino N. Rapid// J. Eur Thyroid 2015. - T.4. - P.14-19.

12. Diana T. Prevalence and clinical relevance of thyroid stimulating hormone receptor-blocking antibodies in autoimmune thyroid disease. / Diana T., Krause J., Olivo P. D.,
Konig J. // Clin Exp Immunol.- 2017. - T. 189. - P.304309.

13. Abeillon-du Payrat J. Predictive value of maternal secondgeneration thyroid-binding inhibitory immunoglobulin assay for neonatal autoimmune hyperthyroidism. / Abeillon-du Payrat J., Chikh K., Bossard N., Bretones P. // Eur J Endocrinol. - 2014. - T.171. - P.451-460.

Матеріал надійшов до редакції 06.12.2018 p. 